\title{
D-dimer levels and COVID-19 severity: Systematic Review and Meta-Analysis
}

\author{
Muhammed Emin \\ DÜZ ${ }^{1}(I D)$ \\ Aydın $\mathrm{BALCl}^{2}(\mathrm{ID})$ \\ Elif MENEKŞE $^{1}($ ID $)$
}

Cite this article as: Düz ME, Balcı A, Menekşe E. D-dimer levels and COVID-19 severity: systematic review and meta-analysis. Tuberk Toraks 2020;68(4):353-360.

\section{Yazışma Adresi (Address for Correspondence)}

Dr. Muhammed Emin DÜZ

Tıbbi Biyokimya Kliniği,

Sabuncuoğlu Şerefeddin Eğitim ve

Araştırma Hastanesi,

AMASYA - TÜRKIYE

e-mail: cerrahemin@gmail.com

CCopyright 2020 by Tuberculosis and Thorax.

Available on-line at www.tuberktoraks.org.com
${ }^{1}$ Department of Medical Biochemistry, Sabuncuoğlu Şerefeddin Training and Research Hospital, Amasya, Turkey

${ }^{1}$ Tıbbi Biyokimya Kliniği, Sabuncuoğlu Şerefeddin Eğitim ve Araştırma Hastanesi, Amasya, Türkiye

${ }^{2}$ Department of Chest Diseases, Afyonkarahisar University Faculty of Medicine, Afyonkarahisar, Turkey

${ }^{2}$ Afyonkarahisar Üniversitesi Tıp Fakültesi, Gögüs Hastalıkları Anabilim Dalı, Afyonkarahisar, Türkiye

\begin{abstract}
D-dimer levels and COVID-19 severity: systematic review and meta-analysis Introduction: Coronavirus disease 2019 (COVID-19) is a fatal and pandemic disease discovered in December 2019 in Wuhan, with lots of asymptomatic cases and a long incubation period. The researchers suggested that high $d$-dimer levels could predict disease severity, lung complications, and thromboembolic events before they occur.
\end{abstract}

Materials and Methods: We searched in PubMed, Scopus, and Web of Science using the keywords "D-dimer" and "coronavirus" or "D-dimer" and "COVID-19." We used Standardized Mean Differences (SMD) to build forest plots of continuous data and assess differences in serum D-dimer concentrations between severe and non-severe patients with COVID-19 disease. We evaluated $p$-value $<0.05$ as statistically significant and preferred $95 \%$ confidence intervals (Cls).

Results: The pooled results of all studies revealed that the D-dimer concentrations were significantly higher in patients with more severe COVID-19 (SMD: $2.32 \mu \mathrm{g} / \mathrm{mL} ; 95 \% \mathrm{Cl}, 0.723 .92 \mu \mathrm{g} / \mathrm{mL}, p<0.001)$. We evaluated severe patients with total D-dimer levels. D-dimer concentrations were significantly higher in severe patients against total COVID-19 patients (SMD: $2.01 \mu \mathrm{g} / \mathrm{mL}$; $95 \% \mathrm{Cl}, 0.25$ to $3.77 \mu \mathrm{g} / \mathrm{mL}, \mathrm{p}=0.08$ ).

Conclusion: We do not know the D-dimer increment mechanism in severe patients yet, but we think that these findings will be useful in the early diagnosis of severe disease and the first treatment.

Key words: D-dimer; COVID-19; thrombus; fibrin 


\section{Öz}

\section{D-dimer seviyeleri ve COVID-19 şiddeti: Sistematik Derleme ve Metaanaliz}

Giriş: Koronavirüs hastalığı 2019 (COVID-19), Aralık 2019'da Wuhan'da keşfedilen, çok sayıda asemptomatik vaka ve uzun bir kuluçka dönemi ile ölümcül ve pandemik bir hastalıktır. Araştırmacılar, yüksek D-dimer seviyelerinin hastalık şiddetini, akciğer komplikasyonlarını ve tromboembolik olayları ortaya çıkmadan önce tahmin edebileceğini öne sürdü.

Materyal ve Metod: PubMed, Scopus ve Web of Science'ta "D-dimer" ve "koronavirüs" veya "D-dimer" ve "COVID-19" anahtar kelimelerini kullanarak arama yaptık. Sürekli verilerin forest plot analizi ve COVID-19 enfeksiyonlu, şiddetli ve şiddetli olmayan hastalar arasındaki serum D-dimer konsantrasyonlarındaki farklılıkları değerlendirmek için Standart Ortalama Farklılıkları (SMD) kullandık. P değerini <0.05 istatistiksel olarak anlamlı olarak değerlendirdik ve \%95 güven aralıklarını (CI) tercih ettik.

Bulgular: Tüm çalışmaların havuzlanmış sonuçları, daha şiddetli COVID-19 hastalarında D-dimer konsantrasyonlarının önemli ölçüde daha yüksek olduğunu ortaya çıkarmıştır (SMD: $2.32 \mu \mathrm{g} / \mathrm{mL} \% 95 \mathrm{Cl}, 0.723 .92 \mu \mathrm{g} / \mathrm{mL}, \mathrm{p}<0.001$ ). D-dimer konsantrasyonları, şiddetli hastalarda tüm COVID-19 hastalarına göre anlamlı olarak daha yüksekti (SMD: $2.01 \mu \mathrm{g} / \mathrm{mL}$; \%95 Cl, $0.25 \mathrm{ila} 3.77 \mu \mathrm{g} / \mathrm{mL}, p=$ 0.08).

Sonuç: Şiddetli hastalarda D-dimer artış mekanizmasını henüz bilmiyoruz ancak bu bulguların ağır hastalı̆̆ın erken teşhisinde ve ilk tedavide faydalı olacağını düşünüyoruz.

Anahtar kelimeler: D-dimer; COVID-19; trombüs; fibrin

\section{INTRODUCTION}

Coronavirus disease 2019 (COVID-19) is the newest infectious disease generated from severe acute respiratory syndrome coronavirus 2 (SARS-CoV-2). Scientists discovered COVID-19 in December 2019 in Wuhan, Hubei, China, and now it became pandemic. As of September 27, 2020, we have more than 32.7 million cases across 188 countries, with more than 992.000 deaths $(1,2)$. Common symptoms are fever, cough, fatigue, shortness of breath, and loss of smell and taste. Although most people have mild symptoms, some could develop acute respiratory distress syndrome (ARDS) caused by cytokine storms, multi-organ failure, septic shock, and blood clots. The known incubation period is two to fourteen days (3). Lots of asymptomatic cases and the long incubation period require us to understand more about the fatal disease. The growing incidence of COVID-19 has put a significant burden on health systems and countries' financial situation globally. Although we diagnose patients early, we find it difficult to get information about the prognosis at an early stage. Clinicians use numerous biochemical and radiological tests at this stage.

COVID-19 causes serious thromboembolic complications in severe patients with the effect of the cytokine storm (4). Scientists found thrombi, endothelial damage, and fibrine in small pulmonary arteries in autopsies, and they discovered that disseminated intravascular coagulation (DIC) was the most critical coagulation abnormality (5). Nevertheless, we do not know if it is a direct effect of the SARS-CoV-2 virus or reflects the coagulation system's activation in response to the severity of the condition. D-dimer is a fibrin degradation product (FDP), releases into circulation when the blood clot dissolves via fibrinolysis (Figure 1). It has two $D$ fragments of the fibrin protein attached by a cross-link (6). The researchers suggested that high D-dimer levels could predict disease severity, lung complications, and thromboembolic events before they even occur. In this way, they aimed to reduce the disease's morbidity and mortality with early diagnosis and treatment (7). However, there is no exact D-dimer value agreed to predict morbidity and mortality. Based on these studies, we conducted a review study on D-dimer levels suggested in the early recognition of patients whose clinical condition will deteriorate.

\section{MATERIALS and METHODS}

We searched in PubMed, Scopus, and Web of Science using the keywords "D-dimer" AND "coronavirus" or "D-dimer" and "COVID-19." The inclusion criteria were: (a) serum D-dimer concentrations in COVID-19 patients, (b) articles dividing COVID-19 patients into disease severeness, (c) studies approved by an ethical committee, and (d) articles published from January 1 , 2020, to the date of the electronic search (September 27, 2020). (e) English written articles only. We excluded case reports and studies involving the pediatric patient population. Independent investigators evaluated titles, abstracts, and full texts. While patients hospitalized in the service or intensive care unit, those with oxygen saturation below $90 \%$, those with lung involvement more than $50 \%$ in CT were included in the severe group; the patients who remained out of 


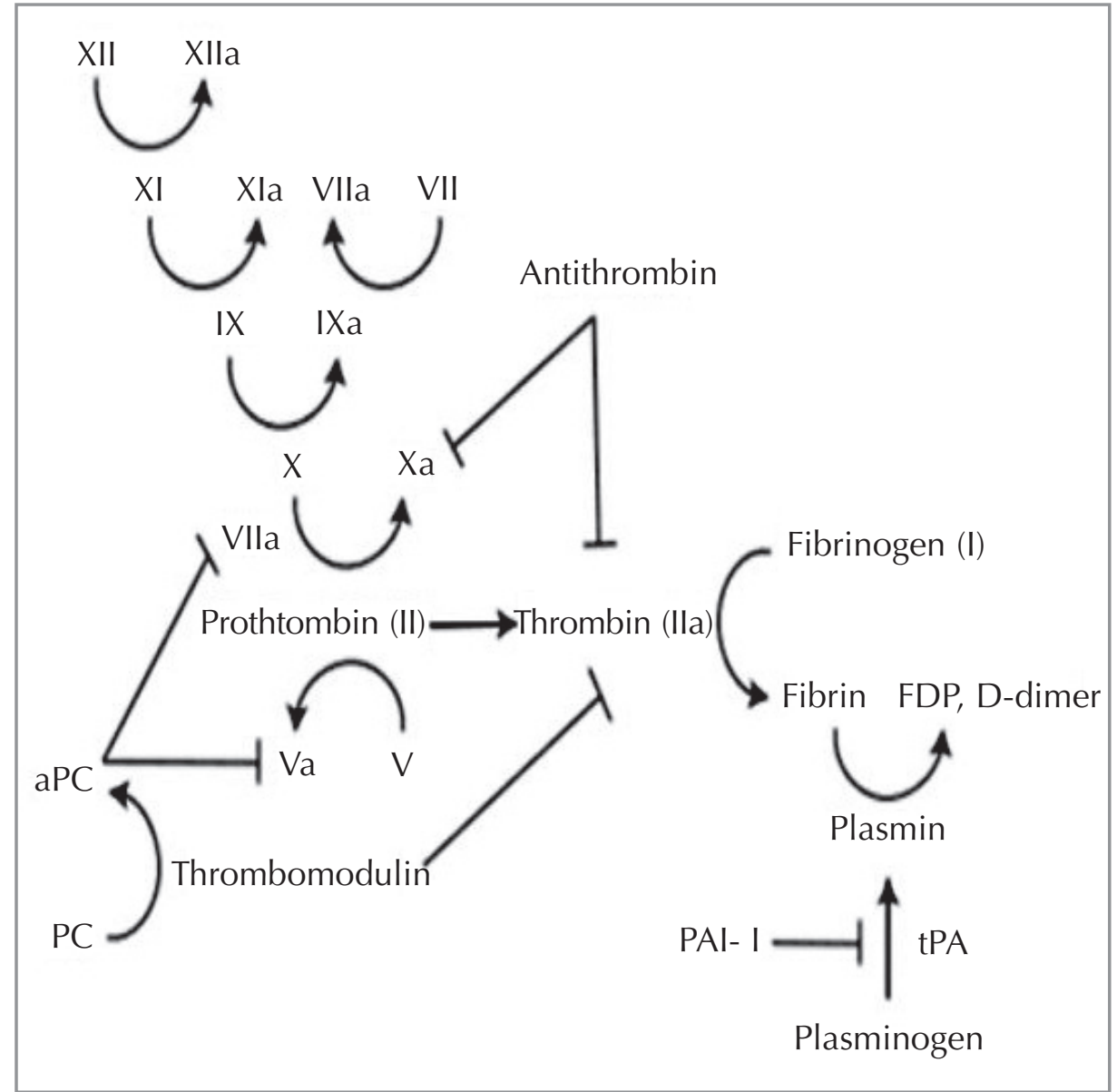

Figure 1. Coagulation and fibrinolysis cascade and D-dimer production. PC: Protein C, aPC: Activated protein C, FDP: Fibrin degradation products, PAI-1: Plasminogen activator inhibitor.

this and received outpatient diagnosis and treatment were included in the non-sever (milder) group. We used Standardized Mean Differences (SMD) to build forest plots of continuous data and assess differences in serum D-dimer concentrations between severe and non-severe patients with COVID-19 disease. We evaluated $p$-value $<0.05$ as statistically significant and preferred 95\% confidence intervals (Cls). We used Forest Plot analysis for D-dimer levels distribution of studies. As stated by the Preferred Reporting Items for Systematic Reviews and Meta-Analyses (PRISMA) guidelines, we prepared our meta-analysis. We evaluated the statistical analysis using Medcalc statistical software (MedCalc Software Ltd, Acacialaan 22, 8400 Ostend, Belgium).

\section{RESULTS}

We performed an electronic literature search, as shown in Figure 2. We conducted our search from 74 studies, chose the final 12, and included them in the meta-analysis (8-19); the total number of COVID-19 patients in these studies was 2801. Among them, 967 (34.5\%) were affected by a severe form of COVID-19 (Table 1). The studies had no common point in determining the severity of the disease. Some studies focused on mortality, some clinical aggravation, other patients with complications.

The differences in serum D-dimer concentrations between COVID-19 patients with or without severe disease in the 12 studies are in Figure 3. In 11 studies, patients with severe COVID-19 displayed higher D-dimer serum concentrations than those with milder forms (mean difference range, 0.6-6.21 $\mu \mathrm{g} / \mathrm{mL}$ ) (8-19). However, there was no significant difference between D-dimer levels in other studies (9). The pooled results of all studies revealed that the D-dimer concentrations were significantly higher in patients 


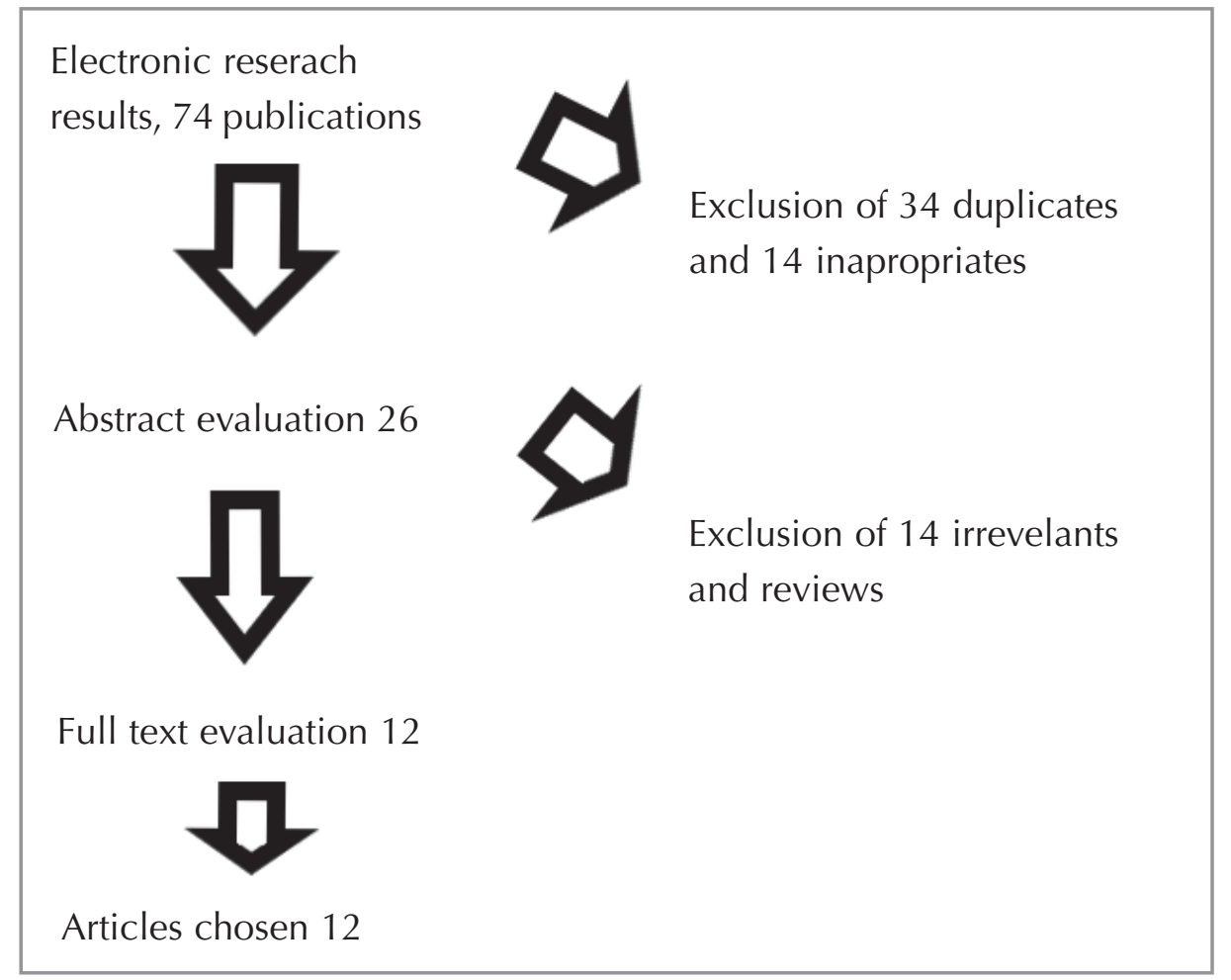

Figure 2. Electronic research diagram via Pubmed, Scopus, and Web of Science.

with more severe COVID-19 (SMD: $2.32 \mu \mathrm{g} / \mathrm{mL}$; $95 \% \mathrm{Cl}, 0.72$ to $3.92 \mu \mathrm{g} / \mathrm{mL}, \mathrm{p}<0.001)$. We evaluated severe patients with total D-dimer levels. D-dimer concentrations were significantly higher in severe patients against total COVID-19 patients (SMD: 2.01 $\mu \mathrm{g} / \mathrm{mL} ; 95 \% \mathrm{Cl}, 0.25$ to $3.77 \mu \mathrm{g} / \mathrm{mL}, \mathrm{p}=0.08$ ) (Figure 4). In meta-regression analysis, there was no correlation either between SMD and age $(p=0.61)$ or between SMD and gender $(p=0.39)$. Results from the forest-plot analysis in 7 studies, according to data, is in Figure 5.

\section{DISCUSSION}

The pathogenesis of COVID-19 is understood more and more over time, and the authors determined that the frequency of thrombotic attacks and the use of heparin to reduce mortality. The researchers reported various thromboembolic events in autopsy reports, histopathology series, and clinical cases. Based on these and coagulation markers, we can say that COVID-19 is a prothrombotic disease. According to Virchow's triad, scientists found vascular endothelium abnormalities, altered blood flow, and platelet dysfunction that lead to multiple various thromboses in COVID-19. Scientists thought that activation of the
Renin-angiotensin-aldosterone system (RAAS), the increase of plasminogen activator inhibitor (PAI-1), and systematic immune response from activated platelets causes thrombogenesis in COVID-19 (20).

D-dimer and fibrinogen levels are higher in hospitalized COVID-19 patients. Contrasting classical DIC (Dissemine intravascular coagulation), prolongation of the aPTT, and or PT is minimal, the platelet count is low (platelet count $\sim 100 \times 10^{9} / \mathrm{L}$ ), and lab results supporting microangiopathy are rare. Infrequently patients with severe COVID-19 infection and multiorgan failure progress to a coagulopathy meeting criteria for overt DIC per ISTH (The ISTH DIC score is calculated using platelet count $(\geq 100.000=0$; $50.000-99.999=1 ;<50.000=2$ ), fibrinogen level $(\geq 100 \mathrm{mg} / \mathrm{dL}=0 ;<100 \mathrm{mg} / \mathrm{dL}=1)$, prothrombin time prolongation above upper limit of normal (ULN) $(<3$ seconds $=0,3-6$ seconds $=1,>6$ seconds $=2)$, and D-dimer $(<2$ times ULN $=0,2-4$ times $U L N=2,>4$ times ULN =3) criteria. ThromboElastoGraphy (TEG) and ROtational ThromboElastoMetry (ROTEM) is under investigation for COVID-19 associated coagulopathy/DIC but should not be used routinely for patient management (21). 


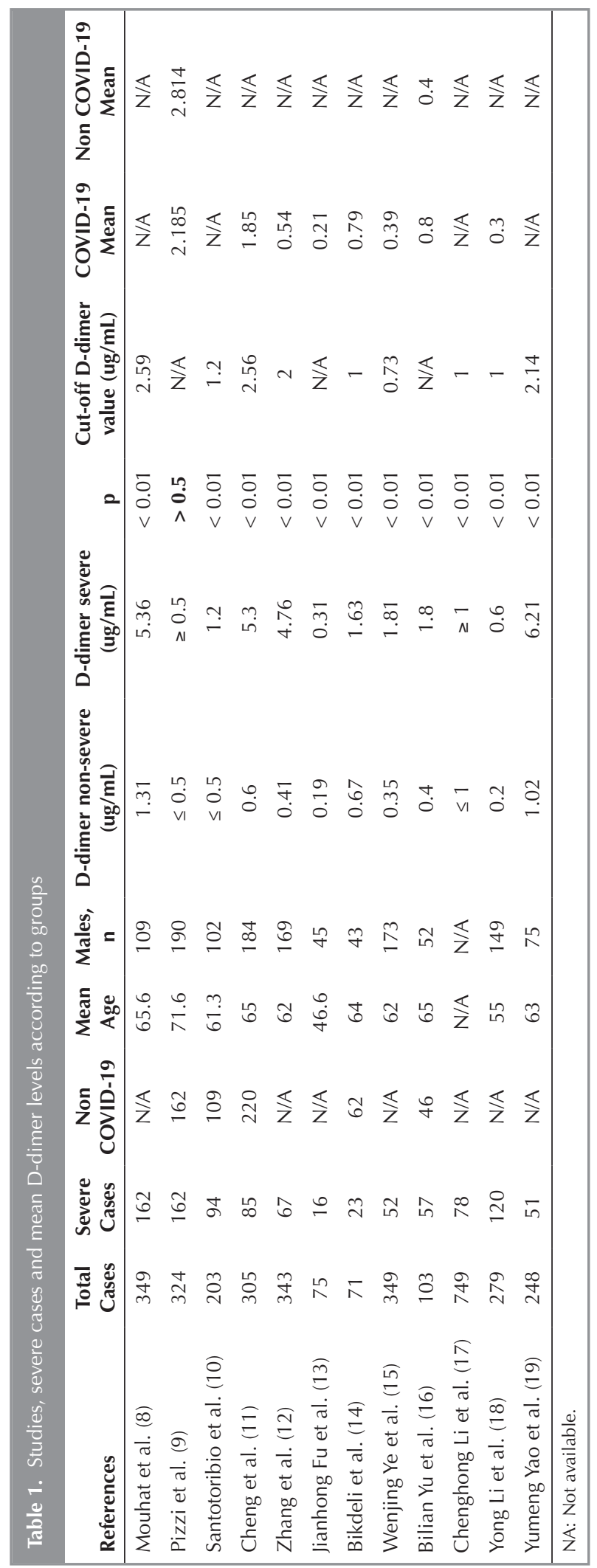




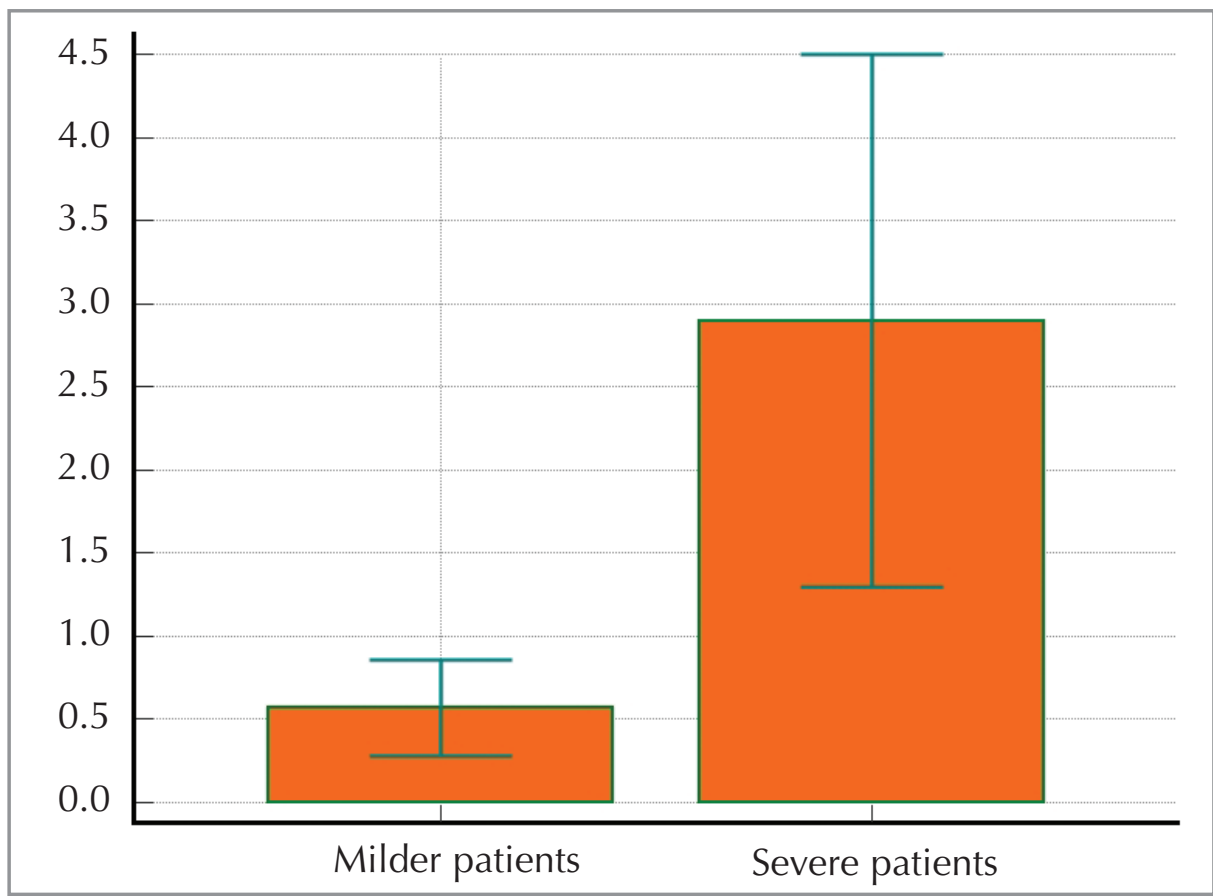

Figure 3. Comparison of D-dimer levels $(\mu \mathrm{g} / \mathrm{mL})$ between milder and severe patients.

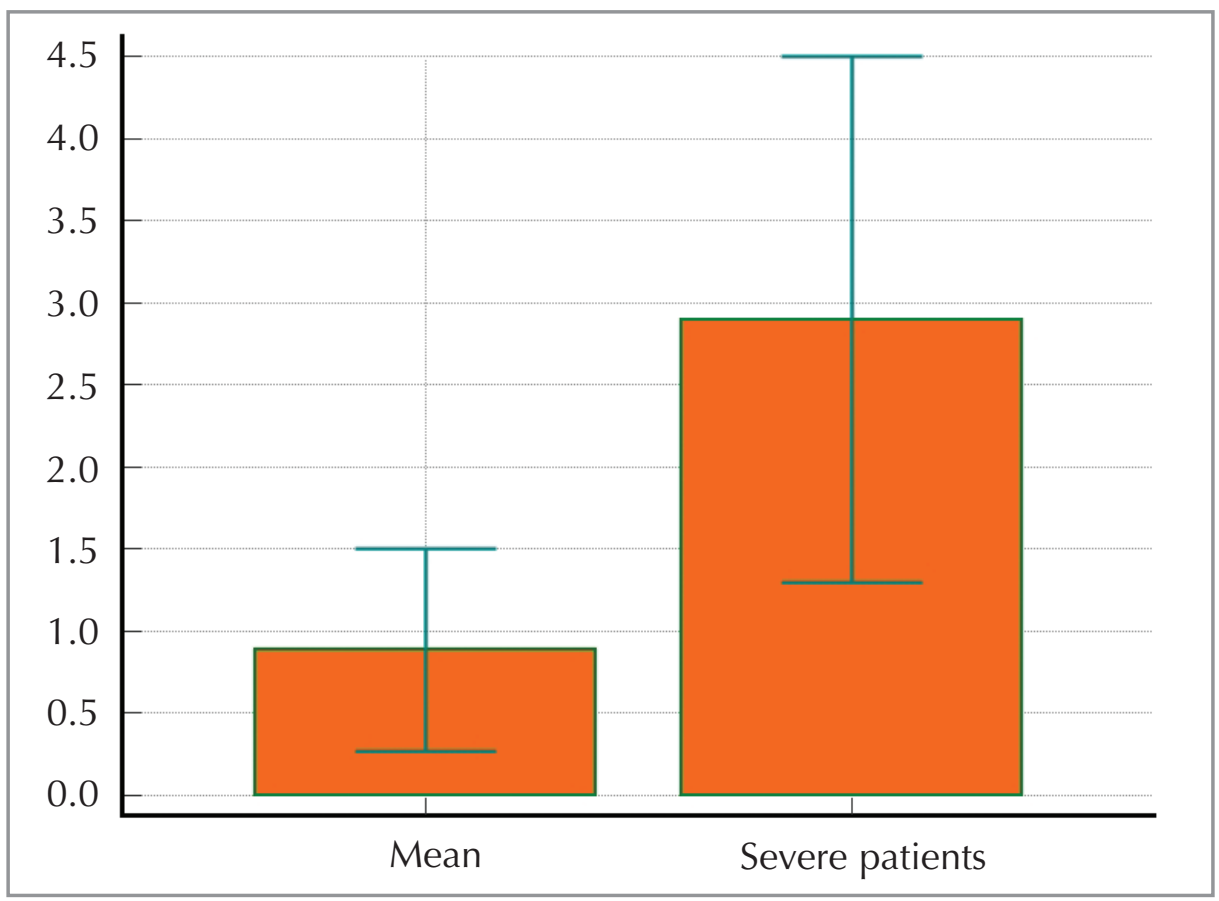

Figure 4. Comparison of D-dimer levels $(\mu \mathrm{g} / \mathrm{mL}$ ) between all patients (mean) and severe patients.

The Fibrinolytic system activates when the coagulation cascade initiates and works to limit the clot. Fibrinolysis is an enzymatic procedure that breaks down the fibrin clot into D-dimer. D-dimer emerges with the dissolution of cross-linked fibrin and is one of the specific indicators of fibrinolysis used to estimate and diagnose pulmonary embolism, DIC, or deep vein thrombosis (22). Apart from venous and 


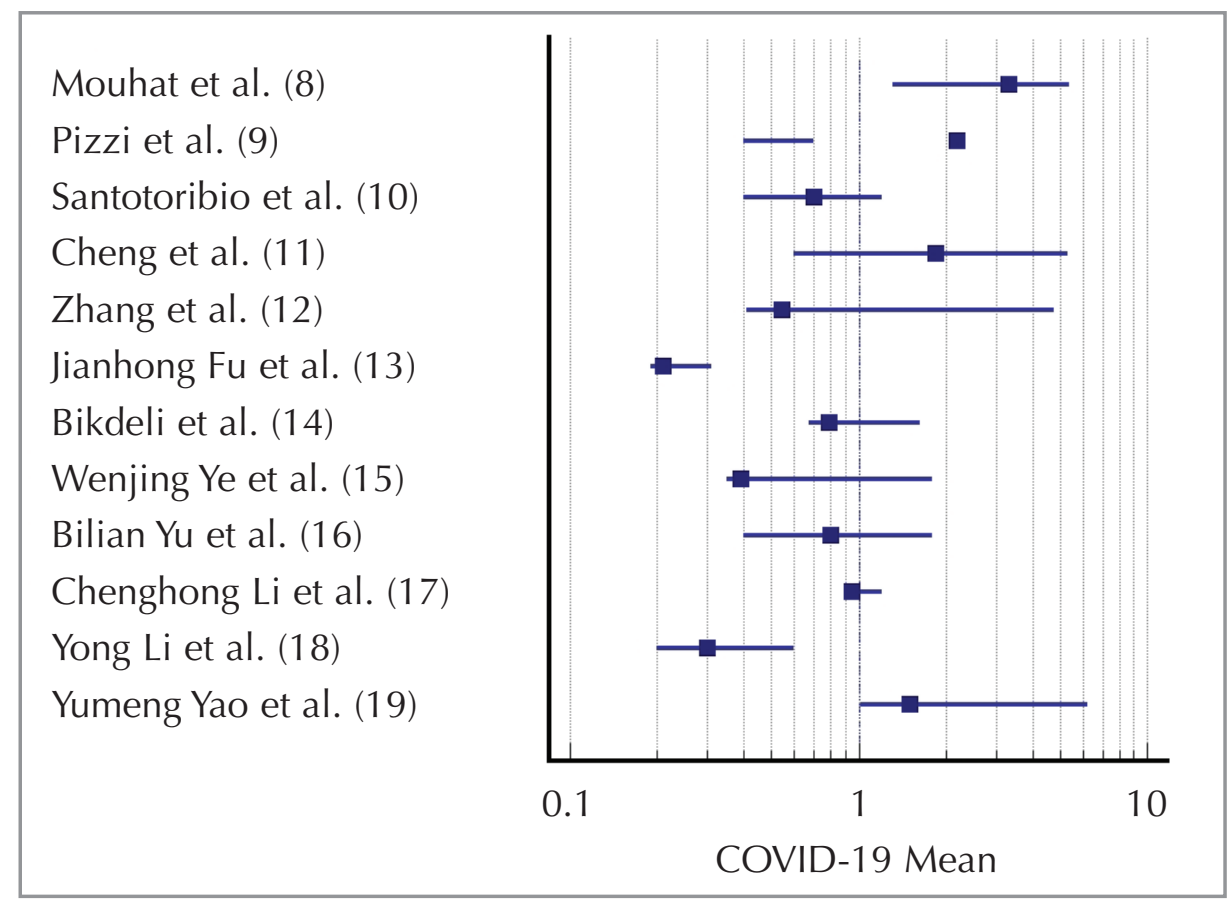

Figure 5. Forest plot analysis of D-dimer levels for analyzed studies. One study had no precise data for the upper limit (9).

arterial thromboembolic events, D-dimer may also elevate due to infections, pregnancy, inflammation, cancer, etc. Also, D-dimer levels correlate with pneumonia. However, D-dimer is not a biomarker for viral pneumonia yet (19).

We performed our study of meta-analysis to determine if the D-dimer levels associate with disease severity. We included 3343 people from 12 publications in our meta-analysis study. Of all that, 2801 were COVID-19 patients, 967 were severe patients. As a result of our meta-analysis study, we determined that D-dimer levels were significantly higher in severe patients compared to mild patients. We also discovered higher D-dimer levels when compared to mean D-dimer levels. We think that these findings will be useful in the early diagnosis of severe disease and the first treatment. The patient's first D-dimer level may associate with an intense course of the disease. In this way, doctors can prevent patients from mortality and morbidity.

One of our review's shortcomings was that D-dimer levels were not available in people who did not have COVID-19. Also, in some of the studies, the cut-off value for D-dimer was unavailable. Studies with cut- off values had different criteria for evaluating the disease's severity, which prevented us from performing pooled analysis for cut-off D-dimer levels.

The pandemic has led the D-dimer studies far above the usual numbers worldwide. Companies faced with D-dimer demand over routine numbers caused severe difficulties in the test kits supply, especially in developing countries. Also, D-dimer kits are expensive than regular biochemical tests and have placed health systems at an unexpected financial burden. Because of all this, although its significance in determining the severity of the disease, we find it appropriate to evaluate D-dimer analyzes according to countries' hospital and health systems. More distant studies are needed to understand how D-dimer levels determine the disease's severity and reach the separator data.

Ethical Committee Approval: Since the study is a meta-analysis, there was no need to receive ethics committee approval.

\section{CONFLICT of INTEREST}

The authors of this meta-analysis declare that they have no conflict of interest. 


\section{AUTHORSHIP CONTRIBUTIONS}

Concept/Design: MED

Analysis/Interpretation: MED, AB

Data Acqusition: EM

Writing: MED, EM

Clinical Revision: $A B$

Final Approval: AB, EM

\section{REFERENCES}

1. ArcGIS. COVID-19 Dashboard by the Center for Systems Science and Engineering (CSSE) at Johns Hopkins University (JHU). Johns Hopkins University. Available from: https://gisanddata.maps.arcgis.com/apps/opsdashboard/index.htm/\#/bda7594740fd40299423467b48e9ecf6 Accessed date: 27 Sept 2020.

2. Du Toit A. Outbreak of a novel coronavirus. Nat Rev Microbiol 2020; 18: 123.

3. European Centre for Disease Prevention and Control. $Q$ \& A on COVID-19: Basic facts. Available from: https://www. ecdc.europa.eu/en/covid-19/facts/questions-answersbasic-facts Accessed date: 18 Sept 2020.

4. Liu B, Li M, Zhou Z, Guan X, Xiang YJ. Can we use the interleukin-6 (IL-6) blockade for coronavirus disease 2019 (COVID-19)-induced cytokine release syndrome (CRS)? Autoimmun 2020; 111: 102452.

5. Dolhnikoff $M$, Duarte-Neto AN, de AlmeidaMonteiro RA, Ferraz da Silva $L F$, Pierre de Oliveira E, Nascimento Saldiva $\mathrm{PH}$, et al. Pathological evidence of pulmonary thrombotic phenomena in severe COVID-19. I Thromb Haemost 2020; 18: 1517-9.

6. Adam SS, Key NS, Greenberg CS. D-dimer antigen: current concepts and prospects. Blood 2009; 113(13): 287887.

7. Lippi G, Favaloro EJ. D-dimer is associated with the severity of coronavirus disease 2019: A pooled analysis. Thromb Haemost 2020; 120: 876-8.

8. Mouat B, Besutti M, Bouiller K. Elevated D-dimers and lack of anticoagulation predict PE in severe COVID-19 patients. Eur Respir J 2020; 56(4): 2001811.

9. Pizzi R, Gini G, Caiano L, Roveda A, Bertù L, Ageno W, et al. Coagulation parameters and venous thromboembolism in patients with and without COVID-19 admitted to the emergency department for acute respiratory insufficiency. Thromb Res 2020; 196: 209-12.

10. Santotoribio JD, Nuñez-Jurado D, Lepe-Balsalobre E. Evaluation of routine blood tests for diagnosis of suspected coronavirus disease 2019. Clin Lab 2020; 66(9): 200522.
11. Cheng A, Hu L, Wang Y, Huang L, Zhao L, Zhang C, et al. Diagnostic performance of initial blood urea nitrogen combined with D-dimer levels for predicting in-hospital mortality in COVID-19 patients. Int I Antimicrob Agents 2020; 56(3): 106110.

12. Zhang L, Yan X, Fan Q, Liu H, Liu X, Liu Z, et al. D-dimer levels on admission to predict in-hospital mortality in patients with COVID-19. I Thromb Haemost 2020; 18: 1324-9.

13. Fu J, Kong J, Wang W, Wu M, Yao L, Wang Z, et al. The clinical implication of dynamic neutrophil to lymphocyte ratio and D-dimer in COVID-19: A retrospective study in Suzhou China. Thromb Res 2020; 192: 3-8.

14. Bikdeli B, Madhavan MV, Gupta A, Jimenez D, Burton JR, Nigoghossian $C D$, et al. Pharmacological agents targeting thromboinflammation in COVID-19: review and Implications for future research. Thromb Haemost 2020; 120(7): 1004-24.

15. Ye W, Chen G, Li X, Lan X, Ji C, Hou M, et al. Dynamic changes of D-dimer and neutrophil-lymphocyte count ratio as prognostic biomarkers in COVID-19. Respir Res 2020; 21(1): 169.

16. Yu B, Li X, Chen J, Quyang M, Zhang H, Zhao X, et al. Evaluation of variation in D-dimer levels among COVID19 and bacterial pneumonia: a retrospective analysis. I Thromb Thrombolysis 2020; 50(3): 548-57.

17. Li C, Hu B, Zhang Z, Qin W, Zhu Z, Zhai Z, et al. D-dimer triage for COVID-19. Academic Emergency Medicine 2020; 27: 612-3.

18. Li Y, Zhao K, Wei H, Chen W, Wang W, Jia L, et al. Dynamic relationship between $D$-dimer and COVID-19 severity. $\mathrm{Br}$ J Haematol 2020; 190(1): e24-e7.

19. Yao Y, Cao J, Wang Q, Shi Q, Liu K, Luo Z, et al. D-dimer as a biomarker for disease severity and mortality in COVID-19 patients: a case-control study. I Intensive Care 2020; 8: 49.

20. Ahmed S, Zimba O, Gasparyan AY. Thrombosis in Coronavirus disease 2019 (COVID-19) through the prism of Virchow's triad. Clin Rheumatol 2020; 39(9): 2529-43.

21. Kutny MA, Rajpurkar M, Alonzo TA, Gerbing RB, Games $A S$, Feusner JH, et al. Evaluation of ISTH DIC score to predict significant bleeding and thrombosis events in pediatric acute promyelocytic leukemia; a report from the children's oncology group AAML0631 trial. Blood 2014; 124 (21): 3669.

22. American Society of Hematology. Lee AYY, Connors JM, Baumann Kreuziger L, Murphy M, Gernsheimer T, Yulia Lin, et al. COVID-19 and Coagulopathy: Frequently Asked Questions. Available from: https://www.hematology.org/ covid-19/covid-19-and-coagulopathy 